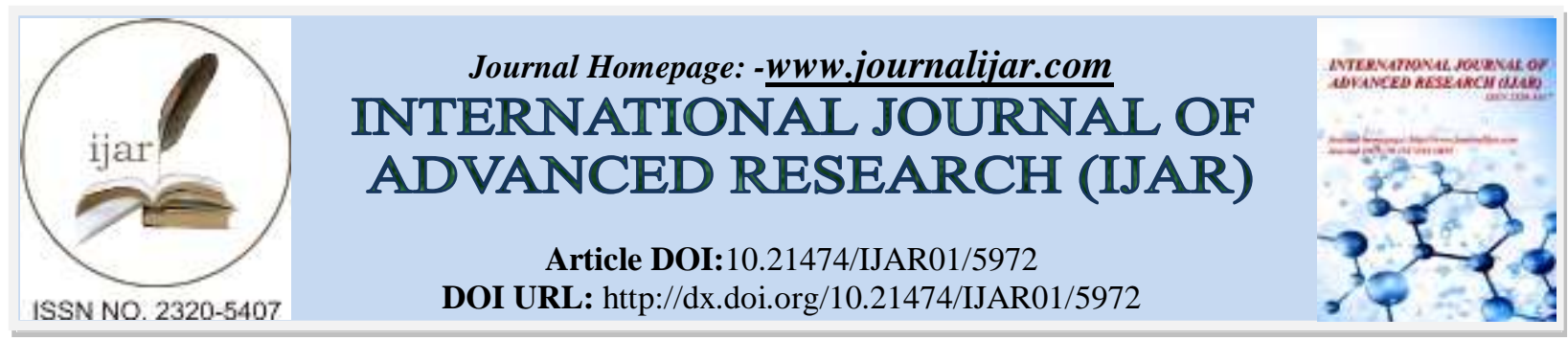

RESEARCH ARTICLE

\title{
ANATOMICAL STUDIES ON THE CRANIAL NERVES AND GANGLIA OF THE HEAD REGION OF THE LIZARD UROMASTYX AEGYPTIA MICROLEPIS. I. THE NERVI "OLFACTORIUS, OPTICUS AND OCTAVUS".
}

\author{
"Dakrory. A. $\mathrm{I}^{1,2}$, Hussein. N. $\mathrm{A}^{1,2}$, Al-Wqdany ${ }^{2}$ and E.A. andMahgoub. A. $\mathrm{F}^{3}$. \\ 1. Department of Zoology, Faculty of Science, Cairo University, Egypt. \\ 2. Department of Biology, Faculty of Science, TaifUniversity, KSA. \\ 3. Department of Zoology, Faculty of Science, Sirt University, Lybia.
}

\section{Manuscript Info}

-........................

Manuscript History

Received: 05 October 2017

Final Accepted: 07 November 2017

Published: December 2017

Key words:-

Uromastyx, Cranial nerves, Olfactorius, Opticus, Octavus.

\section{Abstract}

The olfactory nerve leaves the nasal capsule through separate foramina, i.e., there is no foramen olfactorium advehens and enter the cranial cavity through the foramen olfactorium evehens. An olfactory peduncle is found between the olfactory bulb and the olfactory lobe. It carries pure special somatic sensory fibres. The optic nerve exits the eyeball to the orbital region through a foramen in the sclera cartilage. The two optic nerves met together forming a massive decussation. The octaval nerve has one root, arises from the mid-lateral side of the meylencephalon. It has a large vestibular ganglion, which is located partially intracranial and partially intracapsular. The octaval nerve has an anterior branch and three posterior ones. This nerve has two acoustic foramina in the medial wall of the auditory capsule.

Copy Right, IJAR, 2017,. All rights reserved.

\section{Introduction:-}

In spite of the importance of the study of the cranial nerves of lizards, yet it has not received adequate interest by investigators. The study of the cranial nerves is very important morphologically, systematically, behaviorally, functionally and phylogenetically. The first valuable work of this subject was that of Fischer (1852) who made a comparative study on the cranial nerves of eleven lizards. Although, this work is so early in a date but it is still useful. Another, valuable primitive work was that carried out by Watkinson (1906) on her study of the cranial nerves ofVaranus bivittatus. Willard (1915) published his important work on Anolis carolinemsis. Oelrich (1956) presented an account on these nerves following the dissection of Ctenosaura pectinata. Soliman et al. (1990) gave a fully detailed description on the cranial nerves of Agama pallida and Ptyodactylus hasselquistii. Dakrory (1994) presented a heavy comparative study in the Diplometopon zarudnyi. In case of ophidian, certain studies were presented as those of Hegazy (1976) and Abdel-Kader (2005). Other studies, dealing with special nerves or group of nerves, are found. Dakrory (2005 \& 2011) made a description for the olfactory and terminal nerves on Leptotyphlops cairi and Varanus niloticus, respectively.

Although the study of both the skeletal system (Ramaswami, 1946; Malan, 1946; Barry, 1953; Eyal-Giladi, 1964) and cranial muscles of the agamid lizards attract the interest of anatomists (Herrel and De Vree, 2009), yet the reptilian literatures revealed that there are few studies on their nervous system in general and their cranial nerves in particular. Especially, when compared to their number and their diversity in habit and habitats, such as Soliman et al. (1990) in Agama pallida and Shamakh (2009) on Laudakia stellio. 
The study aims to analyze the fibre components of each nerve and to show the relation between these nerves and the other cranial structures.

\section{Material and Methods:-}

Uromastyx aegyptia is chosen for this study. It is known as Egyptian spiny-tailed lizard or dabb lizard (Capula and Behler, 1989; Zug et al., 2001). This species leaves in desert, with flat areas and light vegetation (Zug et al., 2001). It is herbivorous, but sometime eats young insects with acrodont dentition (Wilms et al., 2010).

Following fertilization, the eggs of this species are collected from Asheera and Al-khummra at Makka and Aldouadmy, KSA, during August 2014.

The embryos removed from their shells, to the aqueous Bouin's fluid for one or two days, followed by washing with 70\% ethyl alcohol. Afterthat, the specimen's heads decalcified using EDTA solution for about 5-6 weeks (according to age and size), with changing the solution every 4 days, the heads dehydrated, cleared, mounted and embedded in paraffin wax and serially sectioned transversely at 10 micrometers' thick. The serial sections are stained with triple Malory's stain (Pantin, 1946).

The serial sections were drawn with the help of the projector. In order to show the position of the nerves and their relations to the different structures of the head, several serial sections are photographed.

\section{Results:-}

Nervus Olfactorius:-

In agamid lizard studied, the fibres of the olfactory nerve orignating from the sensory epithelium collect forming many branches. These branches run posteriorly around the walls of the olfactory chamber at the middle and the posterior region of the nasal cavity. They pass ventral and medial to the parietotectal cartilage and lateral to the internasal septum.

During this caudal course, they approach and unite together into bundles, constituting the olfactory nerve (Figs. $1 \& 2$, N.I). The nerve branches of the ventral and middle areas of the medial olfactory epithelium run posteriorly and dorsally extending ventrolateral to the nervus terminalis, medial to the olfactory epithelium and lateral to the paraseptal cartilage. After a distance, these join with latter nerve.

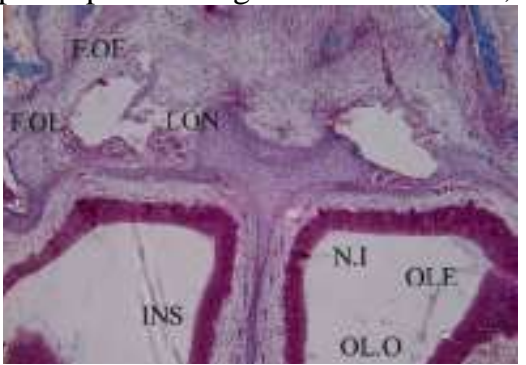

Fig. 1: A photomicrograph of a part of transverse section of the olfactory region of Uromastyx aegyptia showing the foramen olfactorium evehens and another olfactory foramen in the parietotectal cartilage.

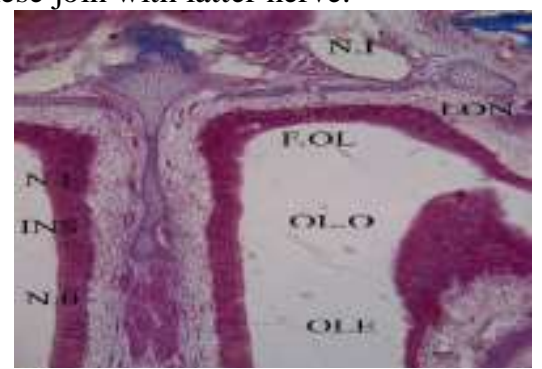

Fig. 2: A photomicrograph of a part of transverse section of the olfactory region of Uromastyx aegyptia illustrating the olfactory foramen, olfactory nerve and nervus terminalis.

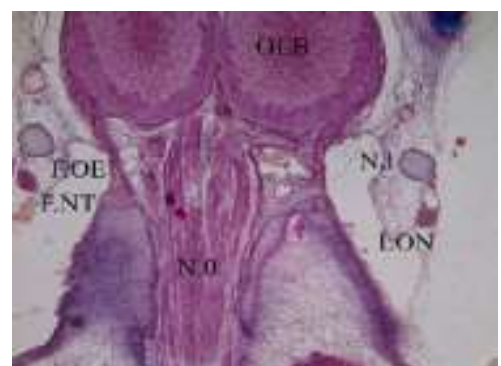

Fig. 3: A photomicrograph of a part of the transverse section of the olfactory region of Uromastyx aegyptia showing the foramina of the olfactory nerve, the foramen olfactorium evehens and the foramen of the terminal nerve.

F.NT, Foramen terminale; F.OE, Foramen olfactorium evehens; F.OL, Foramen olfactorium; INS, Internasal septum; LON, Lamina orbitonasalis; N.0, Nervus terminalis; N.I, Nervus olfactorius; OLB, Olfactory bulb; OL.O, Olfactory organ; OLE; Olfactory epithelium.

The olfactory nerve branches formed from the sensory epithelium of the dorsal part of the medial epithelium, at its anterior end extend posterodorsally to leave the nasal capsule through the posteromedial corner of the largest olfactory foramen (Fig. 1, N.I, F. OL). An olfactory nerve branch is formed from the aggregation of the sensory nerve fibres arising from the most posterior part of the medial olfactory epithelium. This branch extends 
posterodorsally to leave the nasal capsule together with the nervus terminalis through the terminal foramen (Fig. 3 , F.NT).

The olfactory branches of the dorsal epithelium run posteriorly, medial and ventral to the parietotectal cartilage. The branches leave the capsular cavity through a somewhat large olfactory foramen as two or three large bundles (Fig. 1, F.OL). This foramen lies posterior to the parietotectal cartilage, lateral to the internasal septum, posteromedial to the sphene-thmoidal commissure and anterior to the lamina orbitonasalis. Several fine olfactory nerve branches (about six or seven olfactory branches) arise from the posterior olfactory epithelium and leave the capsular cavity separately, each through its own foramen in the lamina orbitonasalis (Fig. 3, F.OL). Leaving the nasal capsule, the nerve branches run posterodorsally till enters the cerebral cavity through a large foramen olfactorium evehns (Figs.1\&3, F.OE). Within the latter cavity, these branches join the main olfactory bulb (Fig. 3, N.I). The olfactory bulbs are connected with the olfactory lobes by olfactory peduncle (stalk). The olfactory nerve carries special somatic sensory fibres and leaves the nasal capsule through many olfactory foramina; there is no foramen olfactorium advehens.

\section{Nervus Opticus:-}

In this study, the optic nerve (Fig. 4, N. II) originates from the retina cells and enters the orbital region through a foramen in the scleral cartilage (Fig. 4, SC). In the latter region, this nerve runs backwards, medial to the sclera, dorsomedial to the rectus inferior muscle and ventromedial to the rectus superior muscle (Fig. 4). After course, in the previous direction, the optic nerve continues ventrolateral to the rectus medialis muscle and medial to the eye ball. Finally, it enters the cranial cavity through a large optic foramen (Fig. 4, OP.F). Here, the two optic nerves met and cross each other forming a massive optic decussation, the optic chiasma (Fig. 5, OP.CH). After this decussation, the optic nerve terminates in the roof of the optic lobe of the mesencephalon.

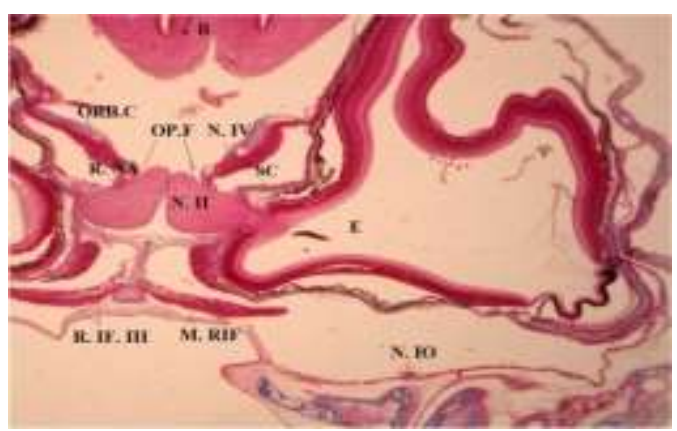

Fig. 4: Aphotomicrograph of a part of a transverse section passing through the orbital region of Uromastyx aegyptia demonstrating the passage of the optic nerve out of the eyeball to the orbit, its entrance the cranial cavity through the optic foramen.

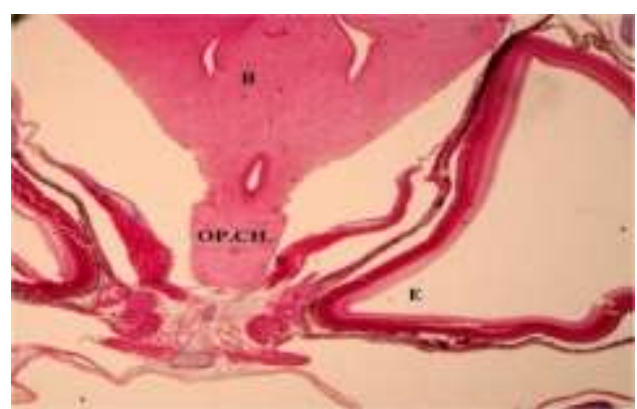

Fig. 5: A photomicrograph of a part of a transverse section passing through the orbital region of Uromastyxaegyptiaillustrating the optic chiasma.

B, Brain; E, Eye; M.RIF, Rectus inferior muscles; N.IO, Infraorbital nerve; N.II, Nervus opticus; N.IV, : Nervus trochlearis; OP.F, Optic foramen; ORB.C, Orbital cartilage; OP.CH, Optic chiasma; R.NA, Ramus nasalis; SC, Scleral cartilage.

\section{Nervus Octavus (Acoustics):-}

In the current studied, the acoustic nerve arises by a stout root from the lateral side of the meylencphalon (Figs. 6\&8, RO.VIII). It extends posteriorly and laterally in the cranial cavity extending dorsal but in contact with the root of the facial nerve till it enters the vestibular ganglion (Figs. 6\&7, G.VE). The anterior part of this ganlgion lies intracranially, between the brain medially, the auditory capsule laterally and the root of octaval nerve ventrally. The posterior part of the vestibular ganglion is located intrcapsular (in the cavity of otic capsule) and in the posterior acoustic foramen. This ganglion has an oval shaped in cross sections (Fig. 8, G.VE).

The vestibular ganglion gives off the ramus ampullaris anterior (Figs. 6, 7\& 8, R. AMA), which enters the otic capsule through the foramen acusticumanterius (Figs. 6\&7 F. AA), that is located in the medial wall of the auditory capsule (AC). The ramus ampullaris anterior runs anteriorly, inside the auditory capsule, passing ventral to the 
semicircular canal and giving off three fine branches to the lateral semicircular canal. Thereafter, it gives off a ventral branch to the utricular macula. Finally, this ramus ends as fine branches on the sensory area (crista) of the anterior semicircular canal.

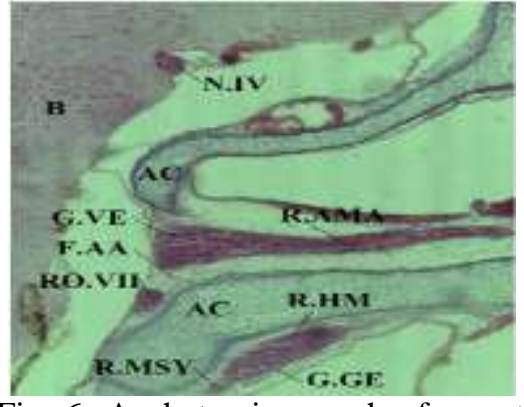

Fig. 6: A photomicrograph of a part of transverse sectionof passing throughthe auditory region of Uromastyx aegyptia showing the anterior root of the nervus facialis from the brain and its connection with the acoustic nerve root as well as, the ramus hyomandibularis. It also, illustrates the octaval root, the vestibular ganglion, the ramus ampullaris anterior and the foramen acousticum anterius.

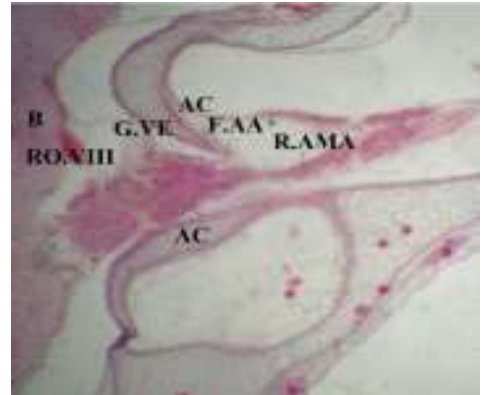

Fig. 7: A photomicrograph of a part of transverse section of passing through the auditory region demonstrating the facial root and the intracranial course of the trochlear nerve. Also, it showsthe ramus ampullaris anterior and the foramen acousticum anterius.

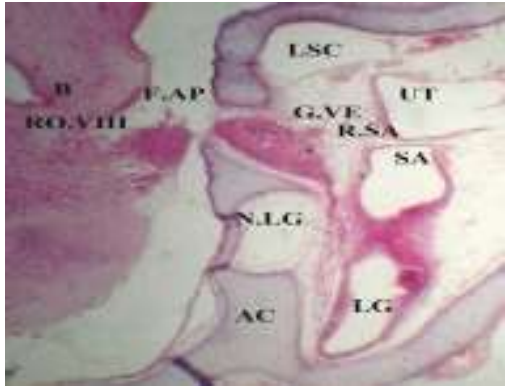

Fig. 8: A photomicrograph of a part of a transverse section passing through the otic region of Uromastyx aegyptia illustrating theoctaval root, the intracapsular part of the vestibular ganglion, the ramus ampullaris posterior, the foramen acousticum posterius and the saccular and lagenar branches.

AC, Auditory capsule; B, Brain; F.AA, Foramen acusticum anterior; F.AP, Foramen acusticum posterior; G.GE, Geniculate ganglion; G.VE, Vestibular ganglion; LG, Lagena; LSC, Lateral semicircular canal; N.LG, Lagenar nerve; N.IV, : Nervus trochlearis; N.VIII, Nervus Octavus; R.AMA, Ramus ampularis anterior; R.HY, Ramus hyomandibularis; R.SA, Sacular ramus; RO.VII, Root of the nervus facialis; SA, Saculus; UT, Utriculus.

From the dorsolateral side of the ganglion issues the saccular branch, which ends in the saccular macula (Fig. 8, N. SA).

The posterior part of the vestibular ganglion enters the auditory capsule through the posterior acoustic foramen (foramen acousticum posterius), which is separated from the foramen acousticum anterior by a cartilaginous bridge (Fig. 8, F.AP). Here, the ganglion gives off the lagner branch. This branch extends ventrally in the posterior direction to end in the lagenar macula (Fig. 8, N. LG). The main ganglion enlarges within the cavum vestibulare and extends posteriorly giving rise to another lagenar branch (Fig. 8, N. LG). At the end, the ganglion gives off from its posterior end the ramus ampullaris posterior (Fig. 8, R. AMP). This branch ends in the sensory neuromasts of the crista of the posterior semicircular canal.

\section{Discussion:-}

In the current study, the olfactory nerve together with the nervi terminalis and vomeronasal issue the capsular cavity as separate bundles through separate foramina. This appears to be common among agamids, a similar condition was found in Agama stellio (Eyal-Giladi, 1964) and in Laudakia stellio (Shamakh, 2009). Also, Malan (1946) recorded a number of foramina for the emersion of these nerves from the capsular cavity in Sceloporus undulates and Iguana iguana. It appears that the exit of these nerves from the olfactory capsule in agamides is modified completely from that found in other lacertilians, where there is a single foramen olfactorium advehens for their exit. Such modifications (Malan, 1946) are due to the backward movement of the dorsal part of the nasal capsule relative to its ventral part. Malan (1946) reported that the nervus vomeronasalis leaves the capsular cavity through a separate foramen which is situated so low down on the posterior face of the capsule as to be located almost ventral in position. This condition is very similar to that found in Laudakia stellio (Shamakh, 2009). On the other hand, a closed foramen olfactoriumadvehens is found in most of the lizards so far described. It is mentioned by Rice (1920) in Eumeces and by Ramaswami (1946) in Calotes. This appears to be due to the fusion between the planum 
antorbitale and the nasal septum. However, the foramen olfactorium advehens of amphisbaenian Diplometopon zarudnyi (Dakrory, 1994) is in the form of a wide incisura and not a closed foramen. This is due to the lack of connection between the planum antorbitale and the nasal septum.

In Ophidia, two conditions are recorded; firstly, a closed foramen olfactorium advehens is recorded in Vipera resselii (Srinivasachar, 1955), Cerastes vipera (Hegazy, 1976), Spalerosophis diadema (Mostafa, 1990) and in Naja haje haje (Abdel-Kader et al., 2000). Secondary, such foramen is in the form of a wide incissure and not a complete foramen in the snakes Typhlops delalandii (Smit, 1949), Malpolon monospessulana (El-Toubiet al., 1973), Psammophis sibilansand Eryx jaculus (Hegazy, 1976) and in both Psammophis schokariand Coluber elegantissinus (Mostafa, 1990).

The presence of a defined fenestra olfactorium advehens appears to be common character among birds (Soliman et al., 1986). However, the nervus olfactorius leaves the capsular cavity through fissure orbitonasalis in Sternus vulgaris (De Kock, 1955) and by means of a bony canal in Colius indicus (Schoonees, 1963).

The numerous pores of the cribriform plate of mammals represnt the fenestra olfactoria advehens, or fenestra cribrosa. The subdivision of the fenestra olfactoriaadvehens is recorded in Galago senegalensis (Kanagasuntheram and Kanan, 1964) and Manis javanica (Jollie, 1968). The subdivision of the fenestra olfactoria advehens seems to be a typical mammalian character, except in monotremes. In such case, nervus terminalis, being combined with the vomeronasal nerve and the ordinay nervus olfactorius leaves the nasal cavity through two separate foramina of the cribriform plate (Hegazy, 1990) in the hedgehog. Earlier, Huber and Guild (1913) and McCotter (1915) dealing with the rabbit and man, respectively, mentioned that the nervus terminalis passes through the cribriform plate anterior to the exit of the vomeronasal nerve.

In the present study, the olfactory nerve together with the nervi terminalis and vomeronasalis enter the cranial cavity through the foramen olfactorium evehens. This agrees with the result of Ramaswami (1946) in Calotes versicolor, Hegazy (1969) in Chalcides ocellatus, Mostafa (1970) in Tarentola mauritanica and Shamakh (2009) in Laudakia stellio. On the other hand, due to the absence of a foramen olfactorium evehens, the nervi olfactorius, terminalis and vomeronasalis enter the cranial cavity through the membranous cranial wall as recorded in the amphisbaenian Diplometopon zarudnyi (Dakrory, 1994).

The lack of the foramen olfactorium evehens seems to be a common pattern in Ophidia (Pringle, 1954; Hammouda, 1963; El-Toubi et al., 1973; Mostafa, 1990; Abdel-Kader et al., 2000). These authors concluded that the lacking of the foramen olfactorium evehens is due to the complete lack of the sphenethmoid commissure.

In Uromastyx aegyptia study, the olfactory bulb is pedunculated. It lies at a considerable distance anterior to the cerebral hemisphere of the brain, to which it is joined by an olfactory peduncle. This was generally found in lizards and snakes by Haller von Hallerstein (1934). The olfactory peduncle has been recorded by many authors in the majority of Sauria and serpents, and hence, it seems a common feature in squamates (Goldby, 1934; Pratt, 1948; Hegazy, 1969 \&1976; Mostafa, 1970\&1990; Abdel-Kader, 1990; Abdel-Kader et al., 2000; Dakrory, 2011;Dakrory and Mahgoub, 2009; El-Ghareeb et al., 2004). In Chelonia, on the other hand, Soliman (1964) found that the olfactory peduncles are absent and the olfactory bulbs sessile, i.e., join the cerebral hemispheres directly.

In the agamid species studied, the optic nerve enters the orbital region through a special foramen in the cartilaginous sclera. This sclera is invested by scleral ossicles. These ossicles were found in Amphisbaena (Rochon-Duvigneaud, 1943) and Trogonophis (Bellairs, 1949), and in Diplometopon zarudnyi (Dakrory, 1994). On the other hand, the ossicles are lacking in Dibamus (Underwood, 1970). In case of ophidians, the sclera is entirely fibrous, lacking ossicles as reported by Underwood (1970), Hegazy (1976) and Mostafa (1990).

In the present study, the nervus opticus made a massive decussation. It is recorded that, the optic chiasma, the crossing of the optic fibres is complete in all vertebrates' classes except mammals Quiring (1950). However, Armstrong (1950) denoted that the decussation at the optic chiasma in Lacerta vivipara was not complete. Only in mammals, about half of the optic fibres in each optic nerve pass to the opposite side and so called incomplete decussation or incomplete crossing over. Eaton (1951) emphasized that this condition is necessary for mammals having binocular vision. 
In the present investigation, the fibres of each optic nerve after crossing beneath the diencephalon, terminates in the optic tectum in the roof of the optic lobes of the mesencephalon. This is the case found in lower vertebrates (Eaton, 1951; Weichert, 1958; Romer, 1962 ; Dakrory, 1994).

In the current study, there is one large optic foramen. This is the case found in most lizards except the burrowing one. The optic foramen is delimited in the orbitotemporal region (Barry, 1953; Kamal, 1961; Hegazy, 1969; Mostafa, 1970\& 1990).

The present study recorded that, the octaval nerve enters the otic capsule through two foramina (anterius and posterius). A case described in the majority of lizards; two acoustic foramina are also found in the majority of snakes (De Beer, 1937; Pringle, 1954; El-Toubi et al., 1973; Hegazy, 1976). On the other hand, three acoustic foramina (anterius, medius and posterior) described in Ptyodactylus annularis (Hafferl, 1921), Mabuya (Rao and Ramaswami, 1952; Gabry et al., 2011; Ibrahim, 2011) and Varanus monitor (Shrivastava, 1964). The latter author stated that, the presence of third foramina in Varanus is an interesting feature.

The condition, in Aves is quite different from that found in lizards and snakes. There are five acoustic foramina in Struthio (Frank, 1954; Lang, 1956), Rhea (Müller, 1961), and in Upupa, Passer and Streptopelia (Soliman et al., 1986). Four foramina were reported in Spheniscus (Crompton, 1953), Pyromelana (Engelbrecht, 1958) and Fulica (Til Macke, 1969). On the other hand, De Beer (1937) mentioned that, in birds, as well as in higher mammals, the foramina acousticus anterius and posterius are known as superius and inferius respectively, this is due to the backward rotation of the auditory capsule.

\section{References:-}

1. Abdel-Kader, I.Y. (1990): Anatomical studies on the cranial nerves of the lizards Agama pallid and Ptyodactulus hasselquistii. Ph.D. Thesis, Fac. Sci. Cairo Univ. Egypt.

2. Abdel-Kader, I.Y.; Soliman, M.A. and Hegazy, R.M. (2000): Innervation of the nasal region of the Egyptian cobra Naja haja haje. J. Egypt. Ger. Soc.Zool. 33: 57-76.

3. Abdel-kader, T.G. (2005): Anatomical studies on the blind snake Leptotyphlops cairi (Family: Leptotyphlopidae). PHD. Thesis, Fac. Sci., Helwan Univ., Egypt.

4. Barry, T.H. (1953): Contributions to the cranial morphology of Agama hispida (Linn.). Ann. Univ.Stellenbosch, 29(A) 2: 55-57.

5. Bellairs, A. d'A. (1949): Observations on the snout of Varanus, and a comparison with that of other lizards and snakes. J. Anat., 83: 116-146.

6. Capula, M. and Behler, S. (1989): Simon \& Schuster's Guide to Reptiles and Amphibians of the World. New York: Simon \& Schuster, pp 259.

7. Crompton, A.W. (1953): The development of the chondrocranium of Spheniscus demersus with special reference to the columella auris of birds. Acta Zool. (Stockh.), 34: 71-146.

8. Dakrory, A.I. (1994): Anatomical studies on the cranial nerves of the Amphisbaenian (Diplometopon zarudnyi). M.Sc. Thesis, Fac. Sci. Cairo Univ. Egypt.

9. Dakrory, A.I. (2005): The innervation of the olfactory apparatus of the blind snake Leptotyphlops cairi (Dumeril and Bibron, 1844). Egypt. J. Zool., 45: 201-214.

10. Dakrory, A.I. (2011): Innervation of the olfactory apparatus of Varanus niloticus (SquamataLacertiliaVaranidae).J. Amer. Sci., 7(9):118-125.

11. Dakrory, A.I. and Mahgoub, A.F. (2009): Innervation of the olfactory apparatus of Echis carinatus (Ophidia: Vibridae). Egypt. J. Zool., 53:535-551.

12. De Beer, G.R. (1937): The development of the vertebrate skull. Clarendon Press, Oxford.

13. De Kock, J.M. (1955): The cranial morphology of Sturnus vulgaris vulgaris Linnaeus. Ann. Univ.Stellenbosch, 31 (A) 3: 153-177.

14. EATON, H.I. (1951): The comparative anatomy of the Vertebrates. New York.

15. El-Ghareeb, A.A.; Abdel-Kader, I.Y. and Mahgoub, A.F. (2004a): The cranial nerves of the snake Natrix tessellate (Ophidia, Colubridae):The nervi terminalis, olfactorius, opticus and octavus. Egypt. J. Zool., 43: 309332.

16. El-Toubi, M. R.; Kamal, A. M. and Zaher, M. M. (1973): The development of the chondrocranium of the snake, Malpolon monospessulana. II. The fully formed stage. Acta Anat., 85: 593-619.

17. Engelbrecht, D. van Z. (1958): The development of the chondrocranium of Pyromelana orixorix. Acta Zool., 39: 115-199. 
18. Eyal-Giladi, H. (1964): The development of the chondrocranium of Agama stellio. Acta Zool., 45: 139-165.

19. Fischer, J.G. (1852): Die Gehirnnerven der Saurieranatomischuntersucht. Abhandl. Naturw. Verein in Hamburg. Abt., 2: 109-212.

20. Frank, G.H. (1954): The development of the chondrocranium of the ostrich. Ann. Univ. Stellenbosch, 30 (A) 4: 179-248.

21. Gabry, M.S; Dakrory, A.I. ; Abdel-Kader,T.G.; Sayed,R.A. and Ibrahim,N.M. (2011):The cranial nerves of Mabuya quinquetaeniata. II. The special sensory nerves"olfactorius, opticus and octavus". J. Egypt. Ger. Soc. Zool., (63B): 43-57.

22. Goldby, F. (1934): The cerebral hemispheres of Lacerta viridis. J. Anat., 68: 157-215.

23. Hafferl, A. (1921): Das knorpelige Neurocranium des Gecko (Platydactylus annularis). Z. Anat. Entw. Gesch.,62: 433-518.

24. Haller von Hallerstein, V. (1934): Anatomied er Wirbeltiere 2/1, herausgegeben von Bolk, Göppert,Kallius, Lubosch. Berlin und Wien.

25. Hammouda, H.G. (1963): Studies on the development of the ophidian skull. Ph.D. Thesis, Fac. Sci., Cairo Univ.

26. Hegazy, M.A. (1969): The cranial nerves of Chalcides ocellatus. M.Sc. Thesis, Fac. Sci., Cairo Univ., Egypt.

27. Hegazy, M.A. (1976): Comparative Anatomical studies on the cranial nerves of Ophidia. Ph.D.Thesis, Fac. Sci., Cairo Univ. Egypt.

28. Hegazy, M.A. (1990): A contribution to the Anatomy of the vomeronasal organ of Jacobson of Mammals with special reference to the Insectivore Hemiechinus auritus (Gmelin). Proc. Zool. Soc. A.R. E., 19: 33-50.

29. Herrel, A. and De Vree, F. (2009): Jaw and hyolingual muscle activity patterns and bite forces in the herbivorous lizard Uromastyx acanthinurus. Arch. Oral. Biol., 54(8): 772-782.

30. Ibrahim, N. M. (2011): The cranial nerves of Mabuya quinquetaeniata. M.Sc. Thesis, Fac. Sci., Helwan Univ., Egypt.

31. Jollie, M.T. (1968): The head skeleton of a new-born Manis javanica with comments on the ontogeny and phylogeny of the mammal head skeleton. Acta Zool., 49: 227-305.

32. Kanagasuntheram, R. and Kanan C.V. (1964): The chondrocranium of a 19 mm C.R. length embryo of Galago senegalensis senegalensis. Acta Zool., 45: 107-121.

33. Lang, C.T. (1956): Das Cranium der Ratitenmitbesond er Berücksichtigung von Struthiocamelus. Z.F. W. Zool., 159: 165-224.

34. Malan, M.E. (1946): Contributions to a comparative anatomy of the nasal capsule and organ of Jacobson of Lacertilia. Ann. Univ. Stellenbosch, 24(A): 69-137.

35. McCotter, R.E. (1915): A note on the course and distribution of the nervus terminalis in man. Anat. Rec., 9(3): 243-246.

36. Mostafa, R.H. (1970): A detailed study on the cranial nerves of the gecko Tarentola mauritanica Linn. M.Sc. Thesis, Fac. Sci., Cairo Univ., Egypt.

37. Mostafa, R.H. (1990): The nervi terminalis, vomeronasalis and olfactorius in Ophidia. Egypt. J. Anat., 13 (2): 259-269.

38. Müller, H.J. (1961): Die Morphologie und Entwicklung des Cranium von Rhea Americana Linne. I. Das knorpellige Neurocranium. Z. F. W. Zool., 165 (3-4): 221-319.

39. Oelrich, T.H. (1956): The anatomy of the head of Ctenosaura pectinata (Iguanidae). Misc. Publ. Mus. Zool. Michigan, 94: 9-122.

40. Pantin, C. F. A. (1946): Notes on microscopical technique for Zoologists. Cambridge, England: Cambridge, University Press.

41. IPratt, C.W.M. (1948): The morphology of the ethmoidal region of Sphenondon and lizards. Proc. Zool. Soc. Lond., 118: 171-201.

42. Pringle, J.A. (1954): The cranial development of certain South African snakes and the relationship of this group. Proc. Zool. Soc. London, 123: 813-865.

43. Quiring, D.P. (1950): Functional Anatomy of the Vertebrates. $1^{\text {st }}$ Ed. New York, Toronto, London. Mc. GrawHill Book Company, Inc. pp. 239-249.

44. Ramaswami, L. S. (1946): The chondrocranium of Calotes versicolor (Daud.) with a description of the Osteocranium of a just-hatched young. Q.J. Micr. Sci., 87: 237-297.

45. Rao, M.K.M. and Ramaswami, L.S. (1952): The fully formed chondrocranium of Mabuya with an account of the adult osteocranium. Acta Zool., 33: 209-275.

46. Rice, E.L. (1920): The development of the skull in the skink, Eumeces quniquelineatus. J. Morph., 34: 119220. 
47. Romer, A. S. (1962): The Vertebrate body. W.B. Saunders Co. Philadelphia and London.

48. ROCHON-DUVIGNEAUD, (1943): Angel and Rochon- Duvigneaud. Qoruted by Underwood, (1970). The eye. In C. Grans and T.S. Parson (Eds), Biology of the Reptilia., 2: 1-97, Academic press, London and New York.

49. Schoonees(1963): Some aspects of the cranial morphology of Colius indicus. Ann. Univ. Stellenbosch, 38: 215-246.

50. Shamakh, A.A. (2009): Innervation of the olfactory apparatus of Laudakia stellio (Reptilia - Squamata Agamidae). J. Zool., 52:453 - 469.

51. Shrivastava, R.K. (1964): The structure and the development of the chondrocranium of Varanus. III. The Otic and Occipital region, Basal plate, Viscero-cranium and certain features of the osteocranium of a juvenile. J. Morph., 106(2): 147-187.

52. Smit, A.L. (1949): Skädelmorfologie en-kinese von Typhlops delalandii (Schlegel). S. Afr. J. Sci., 45: 117-140.

53. Soliman, M.A. (1964): Die Kopfnerven der Schildkröten. Z. F. W. Zool., 169: 215-312.

54. Soliman, M.A.; Hegazy, M.A.; Mokhtar, F.M. and Mostafa, R.H. (1986c): The cranial nerves of Birds. I. The main special sensory nerves, nervus olfactorius, nervus opticus and nervus octavus. Proc. Zool. Soc. A.R.E., 10: 211-232.

55. Soliman, M.A.; Mostafa, R.H.; Hegazy, M.A. and Abdel-Kader, I.Y. (1990): A comparative detailed study on the cranial nerves of Agama pallida (Reuss) and Ptyodactylus hasselquistii (Anderson). II. The nervi glossopharyngeus, vagus, accessorius and hypoglossus. Proc. Zool. Soc., A.R.E., 19: 87-110.

56. Srinivasachar, H.R. (1955): Observations on the development of the chondrocranium in Vipera. Anat. Anz., 101: 219-225.

57. Til Macke, J. (1969): Die Entwicklung des Cranium von Fulicaatra. J. Morph., 113, 2: 229-294.

58. Underwood, G. (1970): The eye. In C. Gans and T.S. Parsons (Eds.), Biology of the Reptilia. Academic Press, London and New York, pp. 1-97.

59. Watkinson, G.B. (1906): The cranial nerves of Varanus bivittatus. J. Morph., 35: 450-472.

60. Weichert, C.K. (1958): Anatomy of the Chordates. McGraw - Hill, New York, Toronto and London.

61. Willard, W.A. (1915): The cranial nerves of Anolis carolinensis. Bull. Mus. Comp. Zool., 59: 17-116.

62. Wilms, T.; Wagner, P.; Shobrak, M.; Lutzmann, N. and Böhme, W. (2010): Aspects of the ecology of the Arabian spiny-tailed lizard (Uromastyx aegyptia microlepis Blanford, 1875) at Mahazat as- Sayd protected area, Saudia Arabia. Salamandra, 46(3): 131-140.

63. Zug, G.; Vitt, L. and Caldwell, J. (2001): Herpetology "An Introductory Biology of Amphibians and Reptiles". $2^{\text {nd }}$ Ed. Academic Press, A Harcourt Science and Technology Company, New York, USA. 